\title{
PENGARUH PENAMBAHAN SERAT GONI TERHADAP KUAT TEKAN DAN KUAT TARIK BETON
}

\author{
M. Nuklirullah \\ Dosen Fakultas Teknik Universitas Batanghari Jambi \\ email: m.nuklirullah@yahoo.com
}

\begin{abstract}
Abstrak
Beton memiliki sifat - sifat kurang baik yaitu getas (brittle) sehingga tidak cukup kuat untuk menahan tarik. Untuk mengatasi sifat kurang baik dari beton dapat dilakukan dengan cara penambahan serat (fiber) pada adukan beton. Tujuannya adalah menulangi beton dengan fiber yang disebarkan secara merata (uniform) kedalam adukan beton. Serat - serat yang telah umum dipergunakan antara lain terbuat dari baja, polymer, atau fiber glass. Salah satu jenis serat yang dapat dipakai adalah serat rosela yang merupakan bahan dari pembuat karung goni yang masuk dalam kategori serat alam. Penelitian ini dilakukan dengan tujuan untuk mengetahui kuat tekan dan kuat tarik beton akibat pengaruh dari penambahan serat goni. Variasi campuran serat yang digunakan adalah $0 \%, 1 \%$ dan 3\%. Benda uji yang digunakan berbentuk silinder dengan ukuran diameter $15 \mathrm{~cm}$ dan panjang $30 \mathrm{~cm}$ untuk uji kuat tekan 3 buah dan uji kuat tarik 3 buah untuk tiap variasi campuran serat goni yang digunakan. Dari hasil penelitian diperoleh bahwa dengan penambahan serat goni menurunkan nilai workabilitynya dan berat volume beton menurun seiring bertambahnya kadar serat. kuat tekan beton dan kuat tarik beton semakin menurun dengan bertambahnya serat goni.

Kata kunci : Beton, Serat, Kuat Tekan, Kuat Tarik
\end{abstract}

\begin{abstract}
Concrete has less good properties, ie brittle so it is not strong enough to withstand tensile. To overcome the bad nature of the concrete can be done by adding fiber (fiber) on the concrete mix. The goal is to reinforce concrete with fiber that is spread uniformly into a concrete mix. The commonly used fibers are made of steel, polymer, or glass fiber. One type of fiber that can be used is roselle fiber which is the material of the burlap maker which belongs to the category of natural fiber. This research was conducted with the aim to know the compressive strength and tensile strength of concrete due to the influence of the addition of jute fiber. Variation of mixed fiber used is $0 \%, 1 \%$ and $3 \%$. The test specimens were used in the form of a cylinder with a diameter of $15 \mathrm{~cm}$ and a length of 30 $\mathrm{cm}$ for a compressive strength test of 3 pieces and a tensile strength test of 3 pieces for each variation of the jute fiber mixture used. The results showed that with the addition of jute fiber decreased the value of workability. The unit weight of concrete decreases with increasing fiber content. Concrete strength and concrete tensile strength decrease with increasing jute fiber.
\end{abstract}

Keywords: Concrete, Fiber, Compressive Strength, Tensile Strength

\section{PENDAHULUAN}

Beton merupakan elemen struktur yang paling banyak digunakan karena keunggulan - keunggulanya antara lain, kuat tekannya tinggi, tahan terhadap api dan cuaca, bahannya yang mudah didapat, mudah dibuat dan harganya murah.

Beton memiliki sifat - sifat kurang baik yaitu getas (brittle) sehingga tidak cukup kuat untuk menahan tarik. Untuk mengatasi sifat kurang baik dari beton 
dapat dilakukan dengan cara penambahan serat (fiber) pada adukan beton. Tujuanya adalah menulangi beton dengan fiber yang disebarkan secara merata (uniform) kedalam adukan beton. Penggunaan serat untuk memperkuat material yang getas telah lama dikenal. Serat - serat yang telah umum dipergunakan antara lain terbuat dari baja, polymer, atau fiber glass. Salah satu jenis serat yang dapat dipakai adalah serat rosela yang merupakan bahan dari pembuat karung goni yang masuk dalam kategori serat alam.

Penelitian ini dilakukan dengan tujuan untuk mengetahui kuat tekan dan kuat tarik beton akibat pengaruh dari penambahan serat goni.

\section{METODOLOGI PENELITIAN}

Pada penelitian ini menggunakan benda uji berbentuk silinder berukuran diameter $15 \mathrm{~cm}$ dan tinggi $30 \mathrm{~cm}$ berjumlah 6 sample benda uji untuk tiap variasi penambahan serat goni yaitu sebesar $0 \%, 1 \%$ dan 3\%. Tiap variasi masing-masing untuk uji kuat tekan 3 sample benda uji dan kuat tarik 3 sample benda uji. Total sample benda uji yang dibuat pada penelitian ini adalah sebanyak 18 sample silinder beton.

Secara keseluruhan tahap-tahap pembuatan dan perawatan benda uji beton adalah sebagai berikut :

1. Persiapan peralatan dan bahan yang diperlukan dalam pelaksanaan.

2. Pemeriksaan bahan dasar di Laboratorium terhadap material yang akan digunakan dalam campuran beton, yaitu pemeriksaan agregat yang meliputi gradasi agregat (modulus halus butiran), pemeriksaan berat jenis , pemeriksaan kadar air dan kadar lumpur agregat.

3. Merencanakan campuran beton (mix design)

4. Menimbang bahan yang dibutuhkan sesuai dengan yang telah ditentukan dalam perencanaan.

5. Pengadukan bahan didahului dengan memasukan pasir dan kerikil kemudian diaduk, masukkan semen PCC, air dan serat goni secara bergantian sampai semua bahan habis.

6. Setelah adukan homogen, diukur nilai slump adukan tersebut.

7. Setelah slump selesai, kemudian adukan beton dimasukan ke dalam cetakan silinder. Pengisian adukan dilakukan tiga tahap, masing - masing 1/3 dari tinggi cetakan. Setiap tahap dipadatkan dengan tongkat baja (dengan ukuran diameter $16 \mathrm{~mm}$ dan panjang $60 \mathrm{~cm}$ yang ujungnya dibulatkan) sebanyak 25 kali.

8. Setelah padat dan cetakan penuh, kemudian permukaanya diratakan.

9. Setelah itu simpan cetakan ditempat yang sejuk, diletakan ditempat yang rata dan bebas dari getaran dan gangguan lain dan dibiarkan 24 jam. Setelah 24 jam benda uji dikeluarkan dari cetakan.

10. Proses selanjutnya adalan perawatan yang dilakukan dengan merendam benda uji di kolam perendaman.

Kuat tekan beton dihitung dengan rumus :

$$
f^{\prime} C=\frac{P}{A}
$$

$\mathrm{P} \quad=$ beban maksimum $(\mathrm{kg})$

Keterangan : f'c = kuat tekan beton $(\mathrm{MPa})$

A = luas penampang benda uji $\left(\mathrm{cm}^{2}\right)$

Nilai kuat tarik beton dihitung dengan rumus sebagai berikut : 


$$
\mathrm{ft}=\frac{2 P}{\pi L D}
$$

Keterangan :

$\mathrm{ft} \quad=$ Kuat tarik belah $(\mathrm{MPa})$

$\mathrm{P} \quad=$ Beban pada waktu belah $(\mathrm{kg})$

$\mathrm{L} \quad=$ Panjang benda uji silinder $(\mathrm{cm})$

D = Diameter benda uji silinder $(\mathrm{cm})$

Data hasil pengujian dilaboratorium kemudian dianalisis sesuai dengan peraturan standar yang berlaku. Analisis data dibagi menjadi dua yaitu analisis data hasil bahan penyusun campuran beton dan analisis data hasil pengujian beton.

\section{HASIL DAN PEMBAHASAN}

\section{Hasil Pemeriksaan Bahan Penyusun}

Hasil pemeriksaan semen secara visual dapat disimpulkan bahwa semen dalam kondisi baik yaitu kemasan tertutup rapat dan tidak ada butiran semen yang menggumpal atau mengeras. Hasil pengamatan serat goni secara visual dapat disimpulkan bahwa serat tidak ada yang rusak dan menggumpal. Hasil pengamatan air secara visual air tampak jernih dan tidak berbau sehingga air dapat digunakan sebagai bahan penyusun campuran beton.

Berikut data hasil uji kadar lumpur dan kadar air agregat kasar dan agregat halus pada tabel 1 berikut ini :

Tabel 1 uji material agregat kasar dan halus

\begin{tabular}{lcc}
\hline \multicolumn{1}{c}{ Penelitian } & Pasir & Kerikil \\
\hline Kadar air & $7,30 \%$ & - \\
Kadar lumpur & $1 \%$ & - \\
Endapan & & \\
Kadar Lumpur Cucian & $11,50 \%$ & $0,50 \%$ \\
\hline
\end{tabular}

Berikut hasil uji analisa saringan dari agregat kasar dan agregat halus ditampilkan pada tabel 2 dan tabel 3 dibawah ini :

Tabel 2 Gradasi agregat kasar (kerikil)

\begin{tabular}{|c|c|c|c|c|c|c|c|}
\hline NO & $\begin{array}{c}\text { Ukuran } \\
\text { Saringan }\end{array}$ & $\begin{array}{c}\text { Berat } \\
\text { Cawan } \\
\text { (gr) }\end{array}$ & $\begin{array}{c}\text { Berat } \\
\text { Cawan + } \\
\text { Agregat } \\
\text { (gr) }\end{array}$ & $\begin{array}{c}\text { Berat } \\
\text { Agregat } \\
\text { (gr) }\end{array}$ & $\begin{array}{c}\text { Prosentase } \\
\text { Agregat } \\
\text { Tertinggal } \\
(\%)\end{array}$ & $\begin{array}{c}\text { Kumulatif } \\
\text { Agregat } \\
\text { Tertinggal } \\
(\%)\end{array}$ & $\begin{array}{c}\text { Persen } \\
\text { Finer } \\
(\%)\end{array}$ \\
\hline 1 & $2 "$ & 65 & 65 & 0 & 0,0 & 0 & 100,0 \\
\hline 2 & $3 / 4 "$ & 65 & 148 & 83 & 8,3 & 8,3 & 91,7 \\
\hline 3 & $3 / 8 "$ & 65 & 340 & 275 & 27,6 & 35,9 & 64,1 \\
\hline 4 & no 4 & 65 & 500 & 435 & 43,6 & 79,5 & 20,5 \\
\hline 5 & no 8 & 65 & 259 & 194 & 19,4 & 98,9 & 1,1 \\
\hline 6 & no 16 & 65 & 75 & 10 & 1,0 & 99,9 & 0,1 \\
\hline 7 & no 30 & 65 & 66 & 1 & 0,1 & 100,0 & 0,0 \\
\hline \multicolumn{2}{|c|}{ JUMLAH } & & & 998 & 100 & & \\
\hline
\end{tabular}


Tabel 3 Gradasi agregat halus (pasir)

\begin{tabular}{cccccccc}
\hline NO & Ukuran & $\begin{array}{c}\text { Berat } \\
\text { Cawan } \\
\text { Saringan }\end{array}$ & $\begin{array}{c}\text { Berat } \\
\text { Cawan }+ \\
\text { Agregat } \\
(\mathbf{g r})\end{array}$ & $\begin{array}{c}\text { Berat } \\
\text { Agregat } \\
(\mathbf{g r})\end{array}$ & $\begin{array}{c}\text { Prosentase } \\
\text { Agregat } \\
\text { Tertinggal } \\
(\mathbf{\%})\end{array}$ & $\begin{array}{c}\text { Kumulatif } \\
\text { Agregat } \\
\text { Tertinggal } \\
(\boldsymbol{\%})\end{array}$ & $\begin{array}{c}\text { Persen } \\
\text { Finer } \\
(\boldsymbol{\%})\end{array}$ \\
\hline 1 & no 4 & 92 & 105 & 13 & 1,3 & 0 & 100 \\
2 & no 8 & 92 & 187 & 195 & 19,5 & 19,5 & 80 \\
3 & no 16 & 92 & 197 & 205 & 20,5 & 40,0 & 60 \\
4 & no 30 & 92 & 502 & 410 & 41,0 & 81,1 & 19 \\
5 & no 60 & 92 & 252 & 160 & 16,0 & 97,1 & 3 \\
6 & no 80 & 92 & 98 & 6 & 0,6 & 97,7 & 2 \\
7 & no 100 & 92 & 102 & 10 & 1,0 & 98,7 & 1 \\
& JUMLAH & & & 999 & 100 & & \\
\hline
\end{tabular}

\section{Pembuatan Benda Uji}

Kemudahan pengerjaan campuran beton dapat dilihat dari nilai slump yang identik dengan tingkat keplastisan beton. Semakin plastis beton, semakin mudah pengerjaanya. Nilai slump yang beragam dari setiap variasi beton disebabkan oleh kadar serat goni pada beton tersebut. Dari hasil pengujian nilai slump menunjukan bahwa nilai slump menurun seiring bertambahnya presentase kadar serat rosela. Data dan hasil Slump adukan beton serat goni dapat dilihat pada tabel di bawah ini :

Tabel 4 Nilai Slump rata- rata benda uji

\begin{tabular}{ccc}
\hline $\begin{array}{c}\text { Kode } \\
\text { benda uji }\end{array}$ & $\begin{array}{c}\text { Kadar } \\
\text { serat }(\%)\end{array}$ & $\begin{array}{c}\text { Nilai Slump rata- } \\
\text { rata }(\mathbf{c m})\end{array}$ \\
\hline BN & $0 \%$ & 16,0 \\
BG1 & $1 \%$ & 8,3 \\
BG3 & $3 \%$ & 4,3 \\
\hline
\end{tabular}

\section{Hasil Pengujian Beton}

Pengujian berat volume beton dilakukan sebelum diadakanya pembebanan terhadap benda uji. Berat volume beton dapat diketahui dengan cara menimbang dan mengukur tinggi serta diameter benda uji, sehingga didapatkan berat dan volume benda uji tersebut. Hasil pemeriksaan berat volume beton rata- rata dapat dilihat pada tabel berikut ini:

Tabel 5 Berat volume rata- rata beton serat goni

\begin{tabular}{ccc}
\hline $\begin{array}{c}\text { Kode } \\
\text { Benda } \\
\text { Uji }\end{array}$ & $\begin{array}{c}\text { Kadar } \\
\text { serat }(\%)\end{array}$ & $\begin{array}{c}\text { Berat Volume Rata - rata } \\
\left(\mathbf{k g} / \mathbf{m}^{\mathbf{3}}\right)\end{array}$ \\
\hline BN & $0 \%$ & 2.390 \\
BG1 & $1 \%$ & 2.360 \\
BG3 & $3 \%$ & 2.330 \\
\hline
\end{tabular}

Dari hasil penelitian pada tabel 5 diatas dapat diketahui bahwa berat volume beton akibat penambahan serat goni menjadi menurun, meskipun penurunnya tidak terlalu signifikan. 
Pengujian kuat tekan beton dilaksanakan setelah benda uji silinder telah berumur 28 hari. Hasil uji kuat tekan rata - rata dengan berbagai variasi kadar serat dapat dilihat pada tabel dan gambar berikut ini:

Tabel 6 Kuat tekan rata - rata

\begin{tabular}{cccc}
\hline $\begin{array}{c}\text { Kode } \\
\text { Benda uji }\end{array}$ & Jenis & Umur & Kuat tekan (MPa) \\
\hline BN & Silinder & 28 Hari & 25,76 \\
BG1 & Silinder & 28 Hari & 19,82 \\
BG3 & Silinder & 28 Hari & 18,12 \\
\hline
\end{tabular}

Dari pengujian kuat tekan beton dengan penambahan serat goni menunjukan bahwa kuat tekan rata - rata benda uji yang ditambah serat goni semakin menurun. Secara berturut -turut prosentase penurunanya sebesar 23,06\% untuk kadar serat $1 \%$ dan $29,66 \%$ pada kadar serat $3 \%$ dari beton dengan kadar serat $0 \%$. Pola retakan pengujian kuat tekan beton serat goni ini dapat dilihat pada gambar di bawah ini.

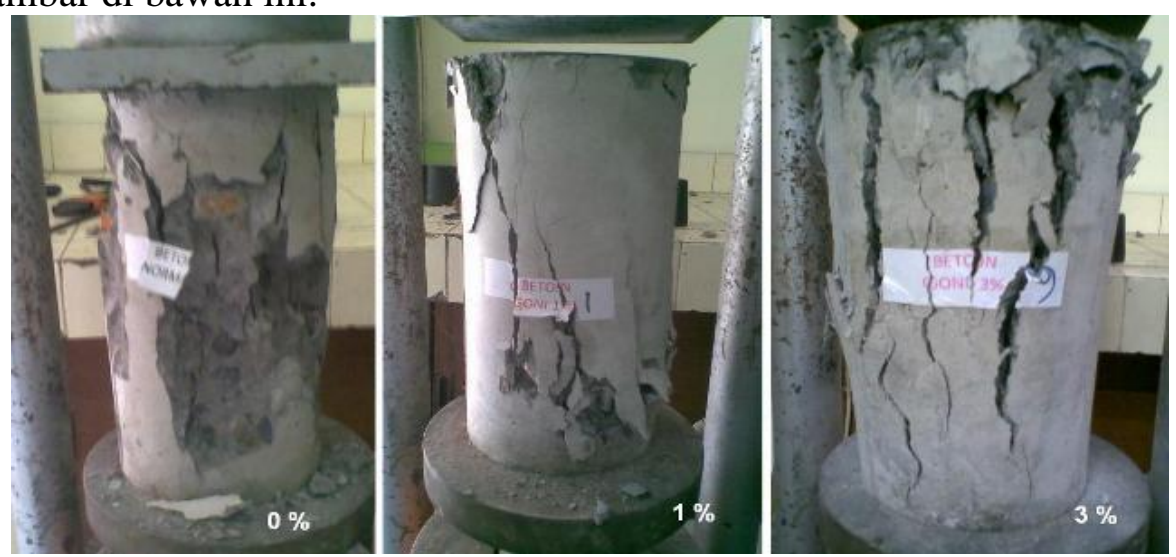

Gambar 1 Pola retakan uji kuat tekan beton serat goni

Pengujian kuat tarik beton dilakukan dengan menggunakan metode uji belah silinder (tensile splitting cylinder test). Hasil pengujian kuat tarik beton dapat dilihat dalam tabel dan gambar berikut ini.

Tabel 7 Kuat tarik rata- rata beton

\begin{tabular}{ccc}
\hline $\begin{array}{c}\text { Kode } \\
\text { Benda uji }\end{array}$ & $\begin{array}{c}\text { Kadar } \\
\text { serat }\end{array}$ & $\begin{array}{c}\text { Kuat tarik rata - rata } \\
(\mathbf{M P a})\end{array}$ \\
\hline BN & $0 \%$ & 2,78 \\
BG1 & $1 \%$ & 2,59 \\
BG2 & $3 \%$ & 2,12 \\
\hline
\end{tabular}

Dari tabel diatas terlihat bahwa kuat tarik rata - rata beton mengalami penurunan dengan adanya penambahan serat goni. Secara berturut -turut prosentase penurunanya sebesar $6,83 \%$ untuk kadar serat $1 \%$ dan $23,74 \%$ pada kadar serat $3 \%$ dari beton dengan kadar serat $0 \%$. Pola retakan pengujian kuat tarik beton serat goni ini dapat dilihat pada gambar di bawah ini. 

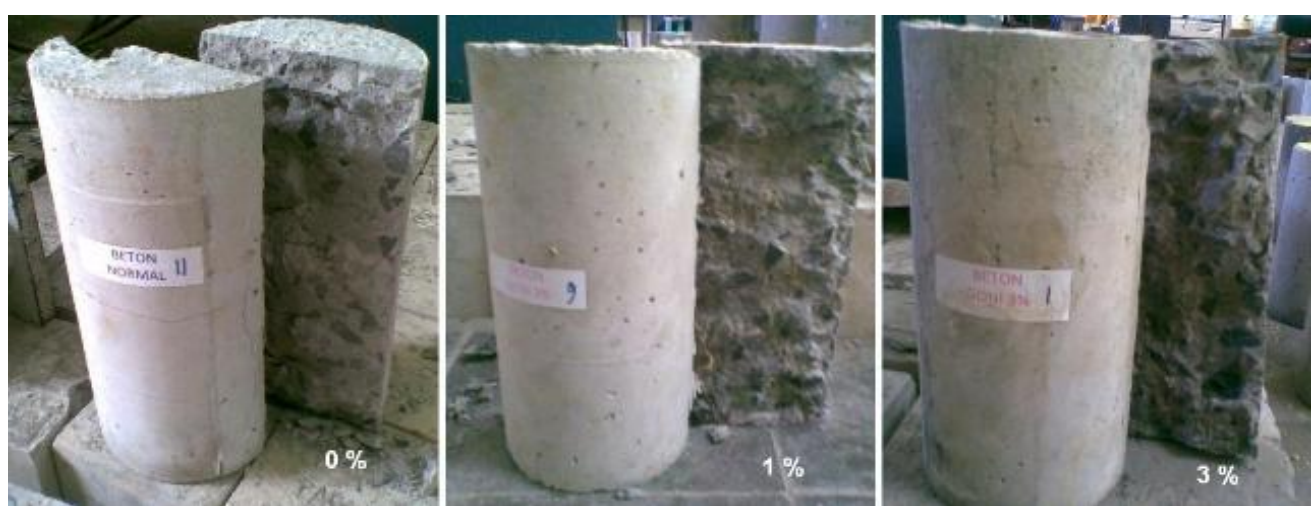

Gambar 2 Pola retakan uji kuat tarik beton serat GONI

\section{KESIMPULAN}

1. Penambahan serat goni berpengaruh terhadap nilai slump, makin besar presentase serat goni pada adukan beton, maka nilai slump makin kecil.

2. Berat volume beton akibat penambahan serat goni menjadi menurun, meskipun penurunya tidak terlalu signifikan.

3. Kuat tekan beton yang ditambah serat goni semakin menurun.Secara berturut turut prosentase penurunanya sebesar 23,06 \% untuk kadar serat 1\% dan 29,66 $\%$ pada kadar serat $3 \%$ dari beton dengan kadar serat $0 \%$.

4. Kuat tarik beton mengalami penurunan dengan adanya penambahan serat rosela. Secara berturut -turut prosentase penurunanya sebesar 6,83\% untuk kadar serat $1 \%$ dan $23,74 \%$ pada kadar serat $3 \%$ dari beton dengan kadar serat $0 \%$.

\section{Saran}

1. Metode pengerjaan beton terutama dalam hal penambahan serat dalam adukan perlu diperhatikan dengan baik sehingga penyebaran serat lebih merata dalam campuran beton.

2. Perlu dilakukan penelitian lebih lanjut dengan jumlah sampel yang lebih banyak dengan interval kadar serat yang lebih variatif agar didapat nilai optimal.

3. Penggunaan alat uji beton hendaknya menggunakan model digital untuk meminimalisir kesalahan pembacaan.

\section{DAFTAR PUSTAKA}

Anonim, 1982. Peraturan Umum Bahan Bangunan Indonesia (PUBI). Jakarta.

Antonius ,2009, Struktur Beton Bertulang, Fakultas Teknik Jurusan Teknik Sipil, Universitas Islam Sultan Agung, Semarang.

Sunggono, K.H. 1984, Buku Teknik Sipil, Nova, Bandung.

SNI 03-2493-1991, Metode Pembuatan Dan Perawatan Benda Uji Beton Di Laboratorium, Badan Standarisasi Nasional

SNI 03-2847-2002, Tata Cara Perhitungan Struktur Beton untuk Bangunan Gedung, Badan Standarisasi Nasional

SNI 15- 7064-2004, Sement Portland Komposit, Badan Standarisasi Nasional

Tjokrodilmuljo, 2007, Teknologi Beton, Biro Penerbit, Teknik Sipil Universitas Gadjah Mada, Yogyakarta. 